\title{
Generated Sequence Data Type
}

National Cancer Institute

\section{Source}

National Cancer Institute. Generated Sequence Data Type. NCI Thesaurus. Code C95661.

A data type comprised of a collection of discrete values in a defined sequence. 